\title{
The relationship between critical thinking disposition, problem solving and empathetic tendency in counsellor candidates*
}

\author{
Cengiz Şahin ${ }^{1 a}$, and Hatice Kumcağız \\ ${ }^{1}$ Ahi Evran University, Department Psychological Counseling and Guidance, Kırşehir, Turkey \\ ${ }^{2}$ Ondokuz Mayis University, Department Psychological Counseling and Guidance, Samsun, Turkey
}

\begin{abstract}
The aim of this research was to examine the relationship between the level of critical thinking disposition, problem solving and empathetic tendencies of the candidate counsellors. Data were collected from a total of 406 counsellors (207 females, 199 males; 103 freshman year, 101 second grade, 98 third grade and 104 senior class) for this purpose. The Turkish Version of California Critical Thinking Disposition Inventory, The Turkish Version of Problem Solving Inventory and Empathetic Tendency Scale were used to collect data. In the data analysis process, descriptive statistics, $t$ tests for independent groups and Pearson Product-Moment Correlation analysis tests were used. According to the first finding, there was no significant difference in the levels of critical thinking, problem solving and empathetic tendency according to gender. Secondly, positive relationships between critical thinking, problem solving, and empathetic tendency levels were achieved.
\end{abstract} Keywords: Critical thinking, problem solving, empathetic tendency.

\section{Introduction}

In contemporary education understanding, the aim of education is not to load students with information, but to facilitate them to become individuals who are aware of their own interests and values, who can analyze, think critically and solve problems. Ideally, they will become individuals who possess elegant identities, who are rational, creative, constructive, sceptical, emotionally and rationally stable, warm-hearted, tolerant, emphatic and respectful to universal norms [1]. In this sense, it is necessity to determine the critical thinking,

\footnotetext{
${ }^{\mathrm{a}}$ Corresponding author: csahim40@gmail.com

* This work was supported by the Ahi Evran University Scientific Research Projects Coordination Unit. Project Number: EGT.E2.17.023
} 
problem solving and empathy levels of psychological counsellors and related trainings are to be organized during their education.

People are bombarded with unlimited sources of information today and have difficulty in selecting and understanding which information is true. It is a necessity of living in society to possess the skills of questioning, searching and decision-making. The adaptation to a developing society is possible therefore with bringing up critically thinking individuals [2]. Paul, who is known for his studies on critical thinking, defines critical thinking as thinking when the person is achieving the act of thinking in order to develop his/her selfthinking [3].

Critical thinking skills are necessary in every field of life. The significance of these skills increases especially in social professions. Finkelman indicates that, in addition to the individuals who work in the health care sector, other individuals such as psychological counsellors, psychologists, teachers etc. who have a direct role in contribution to human life, are expected to possess critical thinking skills [4]. A psychological counsellor should have the skills of looking at a problem from different angles, seeking profound evidence for a subject of belief, making right decisions, problem-solving, being unbiased, behaving flexibly, and making empathy [5].

One receives, processes and uses information while solving a problem [6]. Problem solving is defined as a conscious, demanding and goal-oriented activity [7]. Individuals with high levels of problem-solving skills are open to change and creative with critical thinking skills [8]. Problem solving involves critical thinking, decision making, questioning and empathetic thinking [9]. Therefore, it is important for psychological counsellors to listen to their counselees and try to understand what the real problem is. According to Dökmen, empathy is one's putting himself into another one's shoes, looking from another one's perspective, truly understanding another one's thoughts and feelings as well as conveying this situation. Candidates of psychological counselling should acquire these skills during their education [27].

In the related literature, there are various researches addressing critical thinking $[10,11$, $12,5,13,14,15,16]$, problem solving [17] and empathetic tendencies [18, 19, 20] among different professions both in Turkey and different countries. Yet, there is no specific research dealing with the interaction of these three concepts in the field of psychological counselling. Hence, conducting a study in this context is thought to be beneficial and to bring light to the future studies in this issue.

It is expected that the findings of this study will put forth the relationship between critical thinking, problem solving and empathetic tendency, which is to clarify the importance of some concepts associated with psychological counselling and shed light on further research.

Within the related literature, the aim of the study is to compare the critical thinking, problem solving and empathetic tendencies of psychological counsellor candidates based on gender as well as to examine the relations between these concepts.

\subsection{Objective of the study}

General objective of this study is to examine the relationship between critical thinking, problem solving and empathetic tendency levels of students studying guidance and psychological counselling as per gender level. In direction with the general objective of the study, answers have been sought for following questions:

1. How are students' critical thinking, problem solving and empathetic tendency levels?

2. Do students' critical thinking, problem solving and empathetic tendency levels differ as per gender level? 
3. Is there a significant relationship between students' critical thinking, problem solving and empathetic tendency levels?

\section{Method}

The study was designed as a relational scanning model [21] and made use of the survey technique, which is a commonly applied technique in this model [22].

\subsection{Study group}

The sample of the study consisted of 406 psychological counselling candidates who were studying at the Psychological Counselling and Guidance department in a public university during the 2016-2017 academic year. Among the participant students, 207 were females and 199 were males. 103 were 1st year, 101 were 2nd year, 98 were 3rd year and 104 were 4th year.

\subsection{Data collection tools}

The Turkish Version of the California Critical Thinking Disposition Inventory [23, 24], The Turkish Version of the Problem Solving Inventory $[25,26]$ and the Empathetic Tendency Scale [27] were used as data collection instruments in the study.

\subsubsection{Turkish version of the California Critical Thinking Disposition Inventory (CCTDI-T):}

The original English version of The California Critical Thinking Disposition Inventory CCTDI [23] measures a student's propensity to think critically. Kökdemir, has been administered to identify preservice teachers' attitudes. The index is comprised of 75 questions that represent 7 categories or scales. The Turkish version of the original scale contains 51 items and has 6 factors, Analyticity Open-mindedness, Inquisitiveness, Selfconfidence, Truth-seeking, Systematicity [24]. The internal consistency of the scale was , 85 .

\subsubsection{Turkish version of the Problem Solving Inventory (PSI-T):}

Rather than assessing actual problem solving capabilities, the PSI [25] was designed to assess an individual's perceptions or awareness of one's own problem solving behaviors and attitudes. The inventory's reliability and validity for the Turkish culture has been tested by Taylan [28], by Şahin, Şahin, \& Heppner [26], and by Çam [29]. Statistical tests of the instrument's validity indicated that the measurement model was highly valid. Taylan [28] and Çam [29] found a high relation among subscales which resulted in a factor loading different than that of the original form. For this reason, they strongly suggested that the total score of the PSI must be used instead of using subscale scores separately. The internal consistency of the scale was , 88 .

Empathetic Tendency Scale (ETS): Prepared by Dökmen in order to determine the potentials of individuals to develop empathy in daily life [27]. Nearly half (eight items) of the items in the emphatic tendency scale (ETS) which was developed as a 5-point likert scale and consisting of 20 items was written as negative in order to balance the tendencies of participants to answer positively. The internal consistency of the scale was ,72 [27]. 


\subsection{Data analysis}

In the data analysis process, descriptive statistics, $t$ tests for independent groups and Pearson Product-Moment Correlation analysis tests were used. For significant test, level of $\mathrm{p}<.05$ is accepted. Analysis with the help of the SPSS 20 package software.

\section{Results}

This section includes the results on whether critical thinking, problem solving and empathetic tendencies differed among the candidates of psychological counsellor in terms of their numbers and genders as well as the relationship between the scores of critical thinking, problem solving and empathetic tendencies.

The participants included 336 students 207 (50,9\%) females, $199(49,1 \%)$ males at different class levels in psychological counseling and guidance departments. Distributions of participants as per their class levels have been examined. In this context of students 103 $(25,3 \%)$ were 1 st year, $101(24,8 \%)$ were 2 nd year, $98(24,2 \%)$ were 3 rd year and 104 $(25,7 \%)$ were 4 th year.

\subsection{Students' critical thinking, problem solving and empathetic tendency levels}

Findings related to students' critical thinking, problem solving and empathetic tendency levels in psychological counselors candidate have been specified in Table 1.

Tablo 1. Descriptive statistics

\begin{tabular}{llllll}
\hline Variable & $\mathrm{N}$ & Minimum & Maximum & M & SD \\
\hline Critical thinking & 406 & 51,00 & 306,00 & 209,16 & 20,62 \\
Problem solving & 406 & 32,00 & 192,00 & 91,02 & 3,72 \\
Empathetic tendency & 406 & 20,00 & 100,00 & 71,69 & 7,90 \\
\hline
\end{tabular}

Table 1 shows that students' critical thinking $(209,34 \pm 20,62)$, problem solving $(91,02 \pm 3,72)$ and empathetic tendency $(71,69 \pm 7,90)$ levels is middle.

\subsection{Examination of students' critical thinking, problem solving and empathetic tendency levels as per gender}

The fact whether critical thinking, problem solving and empathetic tendency vary or not as per gender at significant levels has been analyzed by t-test technique for independent groups. Points obtained from the scales by participants basing on result of the examination have been shown in Table 2.

Tablo 2. Statistics related to scale point averages of students as per gender.

\begin{tabular}{llllllll}
\hline Variable & Gender & $\mathrm{N}$ & $\mathrm{M}$ & $\mathrm{SD}$ & $\mathrm{t}$ & $\mathrm{df}$ & $\mathrm{p}$ \\
\hline \multirow{2}{*}{ Critical thinking } & Female & 207 & 210,34 & 18,63 & \multirow{2}{*}{.80} & \multirow{2}{*}{404} & \multirow{2}{*}{.491} \\
& Male & 199 & 208,12 & 23,14 & & & \\
\hline \multirow{2}{*}{ Problem solving } & Female & 207 & 91,90 & 4,18 & \multirow{2}{*}{43} & \multirow{2}{*}{404} & \multirow{2}{*}{.538} \\
& Male & 199 & 90,51 & 3,47 & & & \multirow{2}{*}{.262} \\
\hline \multirow{2}{*}{$\begin{array}{l}\text { Empathetic } \\
\text { tendency }\end{array}$} & Female & 207 & 72,28 & 8,16 & \multirow{2}{*}{1,22} & \multirow{2}{*}{404} & \multirow{2}{*}{.262} \\
\hline
\end{tabular}


It is seen in Table 2 that critical thinking $(210,34 \pm 18,63)$, problem solving $(91,90 \pm 4,18)$ and empathetic tendency $(72,28 \pm 8,16)$ point of male students is higher than critical thinking $(208,12 \pm 23,14)$, problem solving $(90,51 \pm 3,47)$ and empathetic tendency $(71,56 \pm 7,68)$ point of female students $(35,03 \pm 15,02)$. The results indicated no meaningful average score differences among female and male psychological counsellors' critical thinking $(\mathrm{t}(404)=.80)$, problem solving $(\mathrm{t}(404)=.43)$ and emphatic tendencies $(\mathrm{t}(404)=1.22)$ in terms of gender ( $\mathrm{p}>.05)$. In other explanations, critical thinking, problem solving and empathetic tendencies in psychological counselors do not differ according to gender.

\subsection{Relationship between students' critical thinking, problem solving and empathetic tendencies levels}

Relationship between students' critical thinking, problem solving and empathetic tendencies points was calculated as per Pearson correlation technique and results have been presented in Table 3.

Table 3. Correlation between students' critical thinking, problem solving and empathetic tendencies levels

\begin{tabular}{llllll}
\hline Değişkenler & M & SD & $(1)$ & $(2)$ & (3) \\
\hline (1) Critical thinking & 209,16 & 20,62 & 1 & & \\
(2) Problem solving & 91,02 & 3,72 &, $52^{* *}$ & 1 & \\
(3) Empathetic tendency & 71,69 & 7,90 &, $48^{* *}$ &, $44^{* *}$ & 1 \\
\hline
\end{tabular}

$* * \mathrm{p}<0.01$

As seen in Table 4, a statistically low but positive relationship was determined between critical thinking and problem solving $(\mathrm{r}=.52 ; \mathrm{p}<.01)$, and emphatic tendency scores $(\mathrm{r}=.48$; $\mathrm{p}<.01)$, and between problem solving and empathetic tendency scores $(\mathrm{r}=.44 ; \mathrm{p}<.01)$. This result may indicate that critical thinking, problem solving and empathetic tendency are positive covariants.

\section{Discussion and conclusion}

General objective of this study is to examine the relationship between critical thinking, problem solving and empathetic tendency levels of students studying guidance and psychological counselling as per gender level. According to research findings, critical thinking, problem solving and empathetic tendency levels of psychological counsellor candidates are moderate. Secondly, there was no significant difference in the levels of critical thinking, problem solving and empathetic tendency based on gender. Thirdly, positive relationships were found between critical thinking, problem solving, and empathetic tendency levels. These results are in agreement with those of Deniz and Ekinci $[30,31]$.

It is concluded that there is not significant difference between critical thinking levels of psychological counsellor candidates in terms of gender. This finding is in parallel with those of $[11,24,32,33,31,34]$. Özelçi and Aktaş \& Ünlü detected a difference in terms of gender in favour of male participants [35, 36]. Yıldırım, Gurleyuk and Kızıltaş found a significant difference in favour of female participants [37, 9, 38].

Another finding of the research is the lack of significant difference between problem solving levels of psychological counsellor candidates in terms of gender. This result is in line with the previous research in which gender was also an insignificant variable in terms 
of students' problem solving skills $[39,40]$.

It is concluded in the same way that there is not significant difference between empathetic tendency levels of psychological counsellor candidates in terms of gender. This finding is in parallel with several research $[41,42,20]$. When the literature is viewed, it is seen that there are different findings on the effect of gender on empathetic tendency [43, 31, 44]. Some researchers find significant difference in favour of female participants $[45,19]$.

The research results indicate the existence of significant relationships between critical thinking, problem solving and empathetic tendency. According to this, an increase in one variable affects the other positively. These results are supported by those of Korur and Ekinci $[16,31]$.

In light of these findings, additional courses which include critical thinking problem solving and empathetic tendency contents can be delivered to psychological counseling and guidance department students. Specific different topics and challenging concepts can be discussed with students in classroom. Students can benefit from reading related literature, making use of library and internet resources and following popular publications.

\section{References}

1. Şahin, C. Bireyi Tanıma. C. Şahin, (Ed.). Bireyi tanıma teknikleri (s.1-44). Ankara: Pegem Akademi (2016)

2. Ekinci, Ö., Aybek, B. Öğretmen adaylarının empatik ve eleştirel düşünme eğilimlerinin incelenmesi. İlköğretim Online, 9, 2, 816-827 (2010)

3. Paul, R. Critical Thinking. Retrieved From http://outopia.org/teach/resources/ critthink1.pdfrohner, (1993)

4. Finkelman, A. W. Problem solving, decision making, and critical thinking: how do they mix and why bother? Home care provider, 12, 194-198 (2001)

5. Eldeleklioğlu, J., Özkılıç, R. Eleştirel düşünme eğitiminin PDR öğrencilerinin eleştirel düşünme becerilerine etkisi. Türk Psikolojik Danışma ve Rehberlik Dergisi, 3, 29, 25 $36(2008)$

6. Myrick, F., Yonge, O. Preceptor behaviors integral to the promotion of student critical thinking. Journal For Nurses in Staff Development, 18, 131-132 (2002)

7. Erzincanlı, S. \& Zaybek, A. Hemşirelerde eleştirel düşünme eğilimi ve problem çözme becerileri arasındaki ilişki. Uluslararası Hakemli Hemşirelik Araştırmaları Dergisi, 2, 3, 26-38 (2015)

8. Günüşen, N.P., Üstün, B. Hemşirelik öğrencilerinin problem çözme beceri düzeyleri ile kontrol odağı arasındaki ilişki. Dokuz Eylül Üniversitesi Hemşirelik Yüksekokulu Elektronik Dergisi, 4, 72-77 (2011)

9. Gürleyük, G. C. Sınıf Öğretmeni adaylarının çeşitli değişkenler açısından eleştirel düşünme eğilimleri, problem çözme becerileri ve akademik başarı düzeylerinin incelenmesi, Yüksek Lisans Tezi (Basılmamış), Karaelmas Üniv., Zonguldak (2008)

10. Hager, P. \& Kaye, M. Critical thinking ability and teacher effectiveness. Higher Education Research and Development, 10, 2, 177-186 (1991)

11. Mcdonough, M. An Assessment of Critical Thinking at The Community College Level. Unpublished Doctoral Thesis, Columbia University (1997)

12. Akbıyık, C. Eleştirel düşünme eğilimleri ve akademik başarı. Yüksek Lisans Tezi (Basılmamış), Hacettepe Üniversitesi, Ankara (2002)

13. Tufan, D. Öğretmen adaylarının eleştirel düşünme becerileri: Orta doğu teknik üniversitesi yabancı dil öğretmenliği örneği. Yüksek Lisans Tezi (Basılmamış), Orta Doğu Teknik Üniversitesi, Ankara (2008)

14. Yeşilpınar, M. Sınıf Öğretmenlerinin ve Öğretmen Adaylarının Eleştirel Düşünmenin Öğretimine Yönelik Yeterliklerine İlişkin Görüşleri. Yüksek Lisans Tezi (Basılmamış), 
Çukurova Üniversitesi, Adana (2011)

15. Göbel, D. Ş. Sınıf Öğretmenlerinin Eleştirel Düşünme Becerisi Öğretimi Yeterlilikleri ve Uygulamaları. Yüksek Lisans Tezi (Basılmamış), Sakarya Üniv., Sakarya (2013)

16. Korur, E. N., Öncü, E., Küçük Kılıç, S. Eleştirel düşünme ve empatik eğitim ilişkisi: beden eğitimi öğretmeni adayları örneği. Journal of Computer and Education Research, 4, 8, 179-204 (2016)

17. Kesicioğlu, O. S., Güven, G. Okul Öncesi Öğretmen Adaylarinin Özyeterlik Düzeyleri ile Problem Çözme, Empati ve İletişim Becerileri Arasindaki İlişkinin İncelenmesi. Turkish Studies, 9, 5, 1371-1383 (2014)

18. Sargın, N. Rehber Öğretmenlerin Empati Düzeylerinin Geliştirilmesine İlişkin Bir Model Önerisi. Doktora Tezi (Basılmamıș), Dokuz Eylül Üniversitesi, İzmir (1993)

19. Myyry, L., \& Helkama, K. University Students Value Priorities and Emotional Empathy. Educational Psychology, 21, 1, 25-40 (2001)

20. Balcı, E. Sınıf öğretmenlerinin empatik eğilim düzeyleri (Beşiktaş İlçesi Örneği). Yüksek Lisans Tezi (Basılmamış), Yeditepe Üniversitesi, İstanbul (2012)

21. Karasar, N. Bilimsel Araştırma Yöntemi. Ankara: Nobel Akademi (2013)

22. Nachmias, C. F. \& Nachmias D. Research Methods in The Social Sciences. (5th Edition), New York: St. Martin's Press (1996)

23. Facione, P. A., Facione. N. C. \& Giancarlo, C. A. The Disposition toward Critical Thinking: Its Character, Measurement, and Relationship to Critical Thinking Skill. California Academic Press, 20, 1, 91-84 (2000)

24. Kökdemir, D. Belirsizlik Durumlarında Karar Verme ve Problem Çözme. Doktora Tezi (Basılmamış), Ankara Üniversitesi, Ankara (2003)

25. Heppner, P. P. \& Petersen, C. H. The Development and Implications of a Personal Problem Solving Inventory. Journal of Counseling Psychology, 29, 1, 66-75 (1982)

26. Şahin, N., Şahin, N. H. \& Heppner, P. P. The Psychometric Pro-Perties of the Problem Solving Inventory. Cognitive Therapy and Research, 17, 4, 379-396 (1993)

27. Dökmen, Ü. Empatinin Yeni Bir Modele Dayanılarak Ölçülmesi ve Psikodrama ile Geliştirilmesi. Ankara Üniv. Eğitim Bilimleri Fakültesi Dergisi, 21, 1, 156-190 (1988)

28. Çam O. Hemşirelik Yüksekokulu Öğrencilerinde Psikodramanın Empatik Eğilim ve Empatik Beceri Üzerine Etkisi. Ege Üniversitesi Hemşirelik Yüksekokulu Dergisi, 11, 55-63 (1995)

29. Deniz, E. Öğretmen Adaylarının Eleştirel Düşünme Beceri Düzeyleri Üzerine Bir İnceleme. Yüksek Lisans Tezi (Basılmamış), Hacettepe Üniversitesi, Ankara (2009)

30. Ekinci, Ö. Öğretmen Adaylarının Empatik ve Eleştirel Düşünme Eğilimlerinin İncelenmesi. Yüksek Lisans Tezi (Basılmamış), Çukurova Üniversitesi, Adana (2009)

31. Loken, M. L. Critical Thinking Abilities of Undergraduate Entry-Level Athletic Training Students. Unpublished Doctoral Thesis, The University Of South Dakota, USA (2005)

32. Akar, C. İlköğretim öğrencilerinde eleştirel düşünme becerileri. Doktora Tezi (Basılmamış), Gazi Üniversitesi, Ankara (2007)

33. Erdoğan, İ. İlköğretim din kültürü ve ahlak bilgisi öğretmen adaylarının eleştirel düşünme eğilim düzeyleri üzerine bir inceleme. Yüksek Lisans Tezi (Basılmamış), Necmettin Erbakan Üniversitesi, Konya (2012)

34. Özelçi, S. Y. Eleştirel düşünme tutumunu etkileyen faktörler: Sınıf öğretmeni adayları üzerine bir çalışma. Doktora Tezi (Basılmamış), Adnan Menderes Üniversitesi, Aydın (2012)

35. Aktaş, G.S., Ünlü, M. Critical Thinking Skills of Teacher Candidates of Elementary Mathematics. Procedia-Social And Behavioral Sciences, 93, 831-835 (2013)

36. Yıldırım, A. Empati ve Çatışmalar. Ankara: Yargı (2005)

37. Kızıltaş, Y. Sınıf Öğretmeni Adaylarının ve Sınıf Öğretmenlerinin Eleştirel Düşünme 
Eğilimlerinin Çeşitli Değişkenler Açısından İncelenmesi (Van İli Örneği). Yüksek Lisans Tezi (Basılmamış), Yüzüncü Yıl Üniversitesi, Van (2011)

38. Taylan, S. Heppner' in problem çözme envanteri'nin uyarlama, geçerlik ve güvenirlik çalışmaları. Doktora Tezi (Basılmamış), Ankara Üniv., Ankara (1990)

39. Tümkaya, S., İflazoğlu, A. Ç.Ü. Sınıf öğretmenliği öğrencilerinin otomatik düşünce ve problem çözme düzeylerinin bazı sosyo-demografik değişkenlere göre incelenmesi. Ç.Ü. Sosyal Bilimler Dergisi, 6, 6, 143-158 (2000)

40. Tanrıdağ, Ş. R. Ankara'daki Ruh Sağlığı Hizmetlerinde Çalışan Personelin Empatik Eğilim ve Empatik Beceri Düzeylerinin Çeşitli Değişkenler Açısından İncelenmesi. Doktora Tezi (Basılmamış), Hacettepe Üniversitesi, Ankara (1992)

41. Ercoşkun, H. M. Sınıf Öğretmenliği Öğrencilerinin Empatik Eğilimlerinin Çeşitli Değişkenler Açısından İncelenmesi. Yüksek Lisans Tezi (Basılmamış), Atatürk Üniversitesi, Erzurum (2005)

42. Genç, S. Z., Kalafat, T. Öğretmen adaylarının demokratik tutumları ile problem çözme becerilerinin çeşitli değişkenler açısından incelenmesi, Pamukkale Üniversitesi Eğitim Fakültesi Dergisi, 22, 10-22 (2007)

43. Arslanoğlu, C. Farklı Bölümlerde Öğrenim Gören Beden Eğitimi ve Spor Yüksekokulu Öğrencilerinin Empatik Eğilim Düzeyleri ve Saldırganlık İlişkisinin İncelenmesi. Doktora Tezi (Basılmamış), Gazi Üniversitesi, Eğitim Bilimleri Enstitüsü (2012)

44. Schieman S., Van Gundy K. The Personal and Social Links between Age and SelfReported Empathy. Social Psychology Quarterly, 63, 152-174 (2000) 